\title{
Stress and depression levels of mothers who give care to children with cerebral palsy and mental retardation: a comparison study
}

\author{
Serebral palsili ve mental retardasyonlu çocuklara bakım veren annelerin stres ve \\ depresyon düzeyleri: karşılaştırmalı bir çalışma
}

\author{
Erdoğan Kavlak*, Güzin Kara*, Fatih Tekin*, Filiz Altuğ ${ }^{*}$, Nusret Ök**, Hande Şenol*** \\ *Pamukkale University, School of Physical Therapy and Rehabilitation, Denizli \\ ${ }^{* *}$ Pamukkale University, Faculty of Medicine, Department of Orthopedics, Denizli \\ *** Pamukkale University, Faculty of Medicine, Department of Biostatistics, Denizli
}

\begin{abstract}
Purpose:Assessment of mothers who give care to children with Cerebral Palsy (CP) and mentally retarded children (MR) by Bakas Caregiving Outcomes Scale and Caregiver Strain Index.

Materials and methods: Fifty-six mothers living in Denizli (children with $C P n=33$, children with $M R n=23$ ) were included the study. Stress of mothers of $\mathrm{CP}$ and MR children at the process of giving care, were assessed with Bakas Caregiving Outcomes Scale and Caregiver Strain Index and conditions of depression were assessed with Beck Depression Inventory. Motor development levels of children with CP and MR were determined with Classic Motor Development Level.

Results: When Classic Motor Development Level of children with CP were compared with Bakas Caregiving Outcomes Scale of mothers, a statistically significant and negative correlation was found $(p=0.01)$. In comparison of Bakas Caregiving Outcomes Scale of mothers having children with CP and MR, there was a statistically significant difference towards stress burden of mothers with cerebral palsy children was higher $(p=0.03)$.

Conclusion: We found that caregiving stress of mothers of children with $\mathrm{CP}$ was higher. Better motor development level provides less burden of caregiving and depressive symptoms of mothers in disabled children.
\end{abstract}

Pam Med J 2018;11(1):25-31

Key words: Cerebral palsy, mentally retarded, stress, depression, caregiving burden

Özet

Amaç: Serebral Palsili (SP) ve Zihinsel Engelli (ZE) çocuklara bakım veren annelerin Bakas Bakım Verme Etki Ölçeği ve Bakım Verenin Stres Ölçeği ile değerlendirilmesi ile bu annelerin stres ve depresyon düzeylerinin karşılaştırılmasıdır.

Gereç ve yöntem: Çalışmaya Denizli'de yaşayan 56 anne (SP'li-n=33, ZE'li-n=23) dâhil edilmiştir. SP'li ve ZE'li çocuk annelerinin bakım verme sürecindeki stresi Bakım Verenin Stres Ölçeği, bakım verme yükü Bakas Bakım Verme Etki Ölçeği ve depresyon durumları ise Beck Depresyon Ölçeği ile değerlendirilmiştir. Çocukların motor gelişim seviyeleri Klasik Motor Gelişim Seviyesi ile belirlenmiştir.

Bulgular: SP'li çocukların Klasik Motor Gelişim Seviyesi ile annelerinin Bakım Verenin Stres Ölçeği puanları karşılaştırıldığında istatistiksel olarak negatif yönlü anlamlı bir ilişki bulunmuştur $(p=0.01)$. SP'li ve ZE'li çocukların annelerinin Bakas Bakım Verme Etki Ölçeği puanları karşılaştırıldığında istatistiksel olarak anlamlı farklııık bulunmuş $(p=0.03$ ) ve SP'li çocukların annelerinin stres yükü daha yüksek çıkmıştır.

Sonuç: SP’li çocukların annelerinin bakım verme yükünün daha yüksek olduğunu bulduk. Özürlü çocuk annelerinde daha iyi motor gelişim düzeyi, daha düşük bakım verme yükü ve daha az depresif semptomlar yaratır.

Pam Tıp Derg 2018;11(1):25-31

Anahtar sözcükler: Serebral palsi, mental retardasyon, stres, depresyon, bakım verme yükü

Erdoğan Kavlak

Yazışma Adresi: Pamukkale University, School of Physical Therapy and Rehabilitation, Denizli.

e-mail: kavlake@hotmail.com 


\section{Introduction}

Cerebral palsy (CP) is defined as the condition that causes movement and postural disorders and restricted movement due to a non-progressive injury in the developing, immature brain. Mental, sensory, conversation, perception, behavior and seizure disorders frequently accompany the motor disorders in CP $[1,2]$. Being an important disorder that leaves permanent marks on the individual and requires life-long observation, control, care, treatment and rehabilitation, mental insufficiency, similar to other chronic diseases, is a problem that affects all members of the family and the family life in economic, social, emotional, behavioral and cognitive ways [3].

It is known that difficulties in child care and long-term dependency cause strain of the parents [4]. Having a child with CP and mental retardation (MR) increases the stress of the caregivers. The stress of caregiving affects the physiological, psychological, economic and social behavior of the relatives of the patient [5]. Especially the physical and psychological complications of the disease and intense treatment regimens are long-term sources of stress for the patients and caregiving family members [6]. This is why caregiving is a difficult and troublesome process for both the patient and the caregiver [7]. Today, there is no doubt that family needs to be in the caregiving team. Due to the limitations of individuals with chronic disease, the primary caregivers, especially the mother, who is closest to the child, play the most important role in the caregiving process [6]. Finally, the mothers of the children with $\mathrm{CP}$ and MR are the primary carriers of the burden and stress of caregiving.

The aim of this study is evaluating the caregiving mothers of children with $\mathrm{CP}$ and $M R$, and the comparison of the stress and depression levels of the mothers of the $\mathrm{CP}$ and MR diagnosed children.

\section{Matherial and Method}

\section{Participants}

Fifty-six mothers (33 with children with $\mathrm{CP}$ and 23 with children with MR) who live in Denizli were included in the study. The children with $\mathrm{CP}$ and MR were carrying on with their treatments at the special education and rehabilitation centers (Neurodevelopmental Bobath Treatments twice a week and special education once a week).

Informed consents were taken from the mothers and a written permit was taken from the principal of the rehabilitation center (Yagmur Cocuklari special education and Rehabilitation / September 15, 2015) and the ethical principles of the Helsinki Declaration was abided by.

\section{Inclusion criteria}

$\mathrm{CP}$ and MR diagnosed by a pediatric neurologist

The caregiver of the child has to be child's mother

\section{Exclusion criteria}

Any diagnosis other than $\mathrm{CP}$ and $\mathrm{MR}$

Children that whose caregiver was not his/her mother

\section{Methods}

The demographic data of the children with $\mathrm{CP}$ and MR and their mothers who were included in this study was saved. The stress of mothers with children with $\mathrm{CP}$ and MR was evaluated with the Caregiver Strain Index (CSI), the change in their lives during the caregiving process was evaluated with Bakas Caregiving Outcomes Scale (BCOS) and their depressive states was evaluated with Beck Depression Inventdry (BDI). The motor development of children with $\mathrm{CP}$ and MR was evaluated using the Gross Motor Function Classification System (GMFCS) [8] and the method of Classic Motor Development Level (CMDL) detection.

\section{Caregiver Strain Index}

CSI was created by Robinson in 1983 to determine and define the difficulties faced during the caregiving process [9]. The adaptation of the study to the Turkish language was done with Uğur and Fadıloğlu (2010). The scale is made up 13 items. Scores above 7 show the caregiving burden subjectively [10].

\section{Bakas Caregiving Outcomes Scale}

BCOS is used to determine the change in the caregivers' lives with the caregiving process [11]. It was created by Bakas in 1994 in accordance with the Lazarus model to determine the changes in the lives of the families with members who have had a stroke $[6,11,12]$. The adaptation to Turkish, effectiveness and 
reliability of the scale was done by Can et al. [6] in 2010 . The scale is predictive of both negative and positive values. It is made up 15 questions with scores between +3 (best possible score) and -3 (worst possible score) $(-3=1,-2=2,-1=3$, $0=4,+1=5,+2=6,+3=7)$. It is a Likert-type scale that ranges between 1 and 7 . The lowest score is 15 and the highest score is 105 . The score increases with "positive change" and decreases with "negative change" [6].

\section{Beck Depression Inventory}

BDI was created by Beck in 1961 in order to quantitively assess the depressive findings through perception of the participants and its adaptation, effectiveness and reliability study was done in 1988 by Hisli [13]. It has 24 items. Those scoring 17 and above are evaluated as having a risk regarding depressive findings $[6,13]$.

\section{Gross Motor Function Classification System}

It is a classification system, which is scored between the levels 1 and 5 that is used for determining functional level compatible with age of individuals with CP. While an individual easily ensures indoor and outdoor ambulation without requiring complimentary mobility devices in the level 1 , he/she is completely dependent in terms of mobility in the level 5 [14-17].

\section{Classic Motor Development Level}

The level 1 is described that the stage which the child is able to maintain supine or prone position, crawling is defined as level 2 and level 3 is the stage which the child can stand or walk [18].

\section{Statistical Analysis}

All statistical analysis were performed using Statistical Package for the Social Sciences (SPSS) v21.0 software. Continuous variables were defined by the mean \pm standard deviation and categorical variables were defined by number and percent. Mann-Whitney $U$ test was used for comparing two independent groups. Spearman correlation coefficient was used for correlations between continuous variables. $p$ value $\leq 0.05$ were accepted as statistically significant.

\section{Results}

The mean age of the children included in the study with CP was $61.27 \pm 36.33$ months and those with MR were 106.21 \pm 51.12 months. The mean age of the mothers with children with $\mathrm{CP}$ was $34.06 \pm 6.40$ years and that of the mothers with children with MR was $36.04 \pm 5.59$ years. The socio-demographical data of the mothers and children with $\mathrm{CP}$ and MR was shown in Table 1 and Table 2.

Table 1. Demographic characteristics of mothers having children with CP and MR.

\begin{tabular}{|c|c|c|c|c|c|c|}
\hline \multicolumn{4}{|c|}{$\begin{array}{c}\text { Mothers of Children } \\
\text { with CP }\end{array}$} & \multicolumn{3}{|c|}{$\begin{array}{c}\text { Mothers of Children } \\
\text { with MR }\end{array}$} \\
\hline & Minimum & Maximum & $X \pm S D$ & Min. & Max. & $X \pm S D$ \\
\hline Age (year) & 23 & 47 & $34.06 \pm 6.40$ & 27 & 46 & $36.04 \pm 5.59$ \\
\hline $\begin{array}{l}\text { Body Mass Index } \\
\left(\mathrm{kg} / \mathrm{cm}^{2}\right)\end{array}$ & 16.02 & 35.16 & $25.64 \pm 4.87$ & 19.03 & 40.58 & $27.35 \pm 6.42$ \\
\hline \multirow[t]{6}{*}{ Occupation } & & $\mathbf{n}$ & $\%$ & & & $\%$ \\
\hline & Housewife & 25 & 75.8 & & & 73.9 \\
\hline & Worker & 2 & 6.1 & & & 13.0 \\
\hline & Civil Servant & 6 & 18.2 & & & 8.7 \\
\hline & Pensioner & - & - & & & - \\
\hline & Self-Employed & - & - & & & 4.3 \\
\hline \multirow[t]{6}{*}{ Educational Level } & & $\mathbf{n}$ & $\%$ & & & $\%$ \\
\hline & Illiterate & 1 & 3.0 & & & - \\
\hline & Primary School & 15 & 45.5 & & & 60.9 \\
\hline & Middle School & 7 & 21.2 & & & 17.4 \\
\hline & High school & 5 & 15.2 & & & 13.0 \\
\hline & University & 5 & 15.2 & & & 8.7 \\
\hline \multirow[t]{3}{*}{ Social Security } & & $\mathbf{n}$ & $\%$ & & & $\%$ \\
\hline & Yes & 14 & 42.4 & & & 87.0 \\
\hline & No & 19 & 57.6 & & & 13.0 \\
\hline
\end{tabular}


Table 2. Demographic characteristics of children with $\mathrm{CP}$ and MR

\begin{tabular}{|c|c|c|c|c|c|c|}
\hline \multicolumn{4}{|c|}{ Children with CP } & \multicolumn{3}{|c|}{ Children with MR } \\
\hline \multirow[t]{2}{*}{ Age (month) } & Min. & Max. & $X \pm S D$ & Min. & Max. & $X \pm S D$ \\
\hline & 18 & 132 & $61.27 \pm 36.33$ & 17 & 215 & $106.21 \pm 51.12$ \\
\hline \multirow[t]{3}{*}{ Gender } & & $\mathbf{n}$ & $\%$ & $\mathbf{n}$ & & $\%$ \\
\hline & Female & 13 & 39.4 & 7 & & 30.4 \\
\hline & Male & 20 & 60.6 & 16 & & 69.6 \\
\hline \multirow[t]{4}{*}{ Cause of CP } & & $\mathbf{n}$ & $\%$ & $\mathbf{n}$ & & $\%$ \\
\hline & Prenatal & 2 & 6.1 & 2 & & 8.7 \\
\hline & Natal & 30 & 90.9 & 13 & & 56.5 \\
\hline & Postnatal & 1 & 3.0 & 8 & & 34.8 \\
\hline \multirow[t]{6}{*}{ GMFCS } & & $\mathbf{n}$ & $\%$ & $\mathbf{n}$ & & $\%$ \\
\hline & Level 1 & 2 & 6.1 & - & & - \\
\hline & Level 2 & 3 & 9.1 & - & & - \\
\hline & Level 3 & 9 & 27.3 & - & & - \\
\hline & Level 4 & 4 & 12.1 & - & & - \\
\hline & Level 5 & 15 & 45.5 & - & & - \\
\hline \multicolumn{2}{|c|}{ Motor Development Level } & $\mathbf{n}$ & $\%$ & $\mathbf{n}$ & & $\%$ \\
\hline & Apedal & 13 & 39.4 & 2 & & 8.7 \\
\hline & Quadripedal & 6 & 18.2 & 5 & & 21.7 \\
\hline & Bipedal & 14 & 42.4 & 16 & & 69.6 \\
\hline \multirow[t]{5}{*}{ Clinical Type } & & $\mathbf{n}$ & $\%$ & $\mathbf{n}$ & & $\%$ \\
\hline & Spastic & 26 & 78.8 & - & & - \\
\hline & Dyskinetic & 3 & 9.1 & - & & - \\
\hline & Ataxic & 1 & 3.0 & - & & - \\
\hline & Hypotonic & 3 & 9.1 & - & & - \\
\hline \multirow[t]{5}{*}{ Extremity Distri } & & $\mathbf{n}$ & $\%$ & $\mathbf{n}$ & & $\%$ \\
\hline & Hemiparesis & 7 & 21.2 & - & & - \\
\hline & Diplegia & 10 & 30.2 & - & & - \\
\hline & Quadriparesis & 15 & 45.5 & - & & - \\
\hline & Monoparesis & 1 & 3.0 & - & & - \\
\hline
\end{tabular}

No significant correlation was found to exist between the BCOS and the CSI of the mothers with children who have CP $(p=0.30)$. A statistically highly negative significant correlation exists between the CMDL and GMFCS of the children with CP $(p=0.000)$. There was a statistically significant negative correlation between CMDL of children with $\mathrm{CP}$ and their mothers' CSI $(p=0.01)$. Also a statistically significant correlation exists between the GMFCS levels of the children with $\mathrm{CP}$ and the CSI of their mothers $(p=0.000)$. A statistically significant correlation was found between the education levels (EL) of the mothers of children with $\mathrm{CP}$ and their BCOS $(p=0.03)$. However, the correlation between the BDI and BCOS of the mothers of children with $\mathrm{CP}$ was not found to be statistically significant $(p=0.15)$ (Table 3$)$.
A statistically significant negative correlation exists between the BCOS and the CSI of the mothers of children with MR $(p=0.000)$. Upon comparing the BDI and BCOS of the mothers of children with MR, a statistically significant correlation was not found $(p=0.08)$. A statistically significant correlation was found to exist between the CSI and BCOS of mothers of children with MR $(p=0.000)$. A statistically significant correlation was found to exist between the BCOS and the CMDL of children with MR ( $p=0.000)$ (Table 4).

When the stress scales of the mothers of children with $\mathrm{CP}$ and MR are compared, the stress burden of the mothers of children with $C P$ was found to be significantly higher $(p=0.03)$. In the comparison of $\mathrm{BDI}$ of mothers of children with 
Table 3. Relationship between the outcome measurements of participants with CP and their mothers

\begin{tabular}{|c|c|c|c|c|c|c|c|c|c|c|c|c|}
\hline \multirow{2}{*}{$\mathrm{CP}$} & \multicolumn{2}{|c|}{ Bcos } & \multicolumn{2}{|c|}{ CSI } & \multicolumn{2}{|c|}{ BDI } & \multicolumn{2}{|c|}{ CMDL } & \multicolumn{2}{|c|}{ GMFCS } & \multicolumn{2}{|c|}{ EL } \\
\hline & $\mathbf{R}$ & $\mathbf{p}$ & $\mathbf{r}$ & $\mathbf{p}$ & $\mathbf{r}$ & $\mathbf{p}$ & $r$ & $\mathbf{p}$ & $\mathbf{r}$ & $\mathbf{p}$ & $\mathbf{r}$ & p \\
\hline Bcos & - & - & -0.18 & 0.30 & -0.25 & 0.15 & -0.20 & 0.24 & 0.06 & 0.72 & 0.37 & $0.03^{*}$ \\
\hline CSI & -0.18 & 0.30 & - & - & 0.10 & 0.58 & -0.44 & $0.01^{*}$ & 0.51 & $0.00^{*}$ & -0.02 & 0.87 \\
\hline BDI & -0.25 & 0.15 & 0.10 & 0.58 & - & - & -0.04 & 0.80 & 0.12 & 0.47 & -0.29 & 0.09 \\
\hline CMDL & -0.20 & 0.24 & -0.44 & $0.01^{*}$ & -0.04 & 0.80 & - & - & -0.93 & $0.00^{*}$ & -0.07 & 0.67 \\
\hline GMFCS & 0.06 & 0.72 & 0.51 & $0.00^{*}$ & 0.12 & 0.47 & -0.93 & $0.00^{*}$ & - & - & 0.06 & 0.73 \\
\hline EL & 0.37 & $0.03^{*}$ & -0.02 & 0.87 & -0.29 & 0.09 & -0.07 & 0.67 & 0.06 & 0.73 & - & - \\
\hline $\begin{array}{l}\text { BCOS: Bakas } \\
\text { CSI: Caregiv } \\
\text { BDI: Beck De } \\
{ }^{*} p<0,05 \text { acce }\end{array}$ & $\begin{array}{l}\text { aregiver } \\
\text { Stress Ir } \\
\text { ssion Inv } \\
\text { d statisti }\end{array}$ & $\begin{array}{l}\text { comes S } \\
x \\
\text { tory } \\
\text { y signific }\end{array}$ & & $\begin{array}{l}\text { CMDL } \\
\text { GMFC } \\
\text { EL: E }\end{array}$ & $\begin{array}{l}\text { L: Conve } \\
\text { CS: Gros } \\
\text { ducation }\end{array}$ & $\begin{array}{l}\text { tional } \\
\text { Motor } \\
\text { I Levels }\end{array}$ & $\begin{array}{l}\text { tor Deve } \\
\text { nction C }\end{array}$ & $\begin{array}{l}\text { ment Lev } \\
\text { ification }\end{array}$ & stem & & & \\
\hline
\end{tabular}

Table 4. Relationship between the outcome measurements of participants with MR and their mothers

\begin{tabular}{|c|c|c|c|c|c|c|c|c|}
\hline \multirow[b]{2}{*}{ MR } & \multicolumn{2}{|c|}{ BCOS } & \multicolumn{2}{|c|}{ CSI } & \multicolumn{2}{|c|}{ BDI } & \multicolumn{2}{|c|}{ EL } \\
\hline & $\mathbf{r}$ & $\mathbf{p}$ & $\mathbf{r}$ & $\mathbf{p}$ & $\mathbf{r}$ & $\mathbf{p}$ & $\mathbf{R}$ & $\mathbf{p}$ \\
\hline CSI & -0.53 & $0.00^{*}$ & - & - & 0.63 & $0.00^{*}$ & -0.13 & 0.55 \\
\hline CMDL & 0.53 & $0.00^{*}$ & -0.36 & 0.08 & -0.30 & 0.15 & 0.50 & $0.01^{*}$ \\
\hline EL & -0.02 & 0.90 & -0.13 & 0.55 & -0.16 & 0.44 & - & - \\
\hline \multicolumn{3}{|c|}{ BCOS: Bakas Caregiver Outcomes Scale } & \multicolumn{6}{|c|}{ CMDL: Conventional Motor Development Level } \\
\hline \multicolumn{3}{|c|}{ CSI: Caregiver's Stress Index } & \multicolumn{6}{|c|}{ GMFCS: Gross Motor Function Classification System } \\
\hline
\end{tabular}

$\mathrm{CP}$ and MR, a statistically significant difference was not found $(p=0.72)$. Also, there was no statistically significant difference between the BCOS of the mothers of children with CP and $\operatorname{MR}(p=0.46)$ (Table 5).

\section{Discussion}

In this study, the mothers of children with $\mathrm{CP}$ were found to be significantly more stressindexed than the mothers of children with MR. This is thought to be due to the fact that CP is

Table 5. Outcome measurements of mothers of children with CP and MR

\begin{tabular}{|c|c|c|c|}
\hline & & $\begin{array}{c}\text { Mothers of Children } \\
\text { with CP }\end{array}$ & $\begin{array}{c}\text { Mothers of Children } \\
\text { with MR }\end{array}$ \\
\hline \multirow{2}{*}{ Bcos } & $\mathrm{X} \pm \mathrm{SD}$ & $51.63 \pm 19.96$ & $55.65 \pm 20.46$ \\
\hline & $\mathbf{p}$ & \multicolumn{2}{|c|}{0.46} \\
\hline \multirow{2}{*}{ CSI } & $\mathrm{X} \pm \mathrm{SD}$ & $7.24 \pm 3.70$ & $4.82 \pm 4.53$ \\
\hline & $\mathbf{p}$ & \multicolumn{2}{|c|}{$0.03^{*}$} \\
\hline \multirow{2}{*}{ BDI } & $\mathrm{X} \pm \mathrm{SD}$ & $15.75 \pm 9.84$ & $14.69 \pm 12.40$ \\
\hline & $\mathbf{p}$ & \multicolumn{2}{|c|}{0.72} \\
\hline \multicolumn{4}{|c|}{ BCOS: Bakas Caregiver Outcome Scale } \\
\hline \multicolumn{4}{|c|}{ CSI: Caregiver's Stress Index } \\
\hline \multicolumn{4}{|c|}{ BDI: Beck Depression Inventory } \\
\hline${ }^{*} p<0.05$ accepted stati & & & \\
\hline
\end{tabular}


a much more complex situation than MR and is caused by a multitude of other problems that accompany $\mathrm{CP}$.

When the depression levels of the mothers were examined, it was determined that only the mothers of the children with MR had negative effects on the caregiving stress. This is thought to be due to the adverse effects of current mental problems, although there is no gross motor function problem in children with MR.

In the study, it is observed that the care burden of the mothers in both groups is different and this difference is more in the direction of mothers of children with CP. The factor leading to this situation is thought to be the inadequacy of gross motor function in children with CP.

In our study, we found that the stress in the caregiving process is higher in mothers of the children with CP when compared to those of the children with MR. When investigated in terms of the motor development levels of the children with $\mathrm{CP}$ and the caregiving stress burden of the mother, it was found that the disability level of the children with CP directly affects the anxiety and stress levels of the mother $[2,19]$. The dependency of the child with $\mathrm{CP}$ increases as does his/her level of disability and it was found that the mother's anxiety and stress levels increase accordingly [20,21].

Based on the data collected from our study, a negative correlation was found between the motor development of the children with CP and the caregiver's strain index. The increase in the motor development levels of the children with $\mathrm{CP}$ and MR caused an increase in the BCOS levels of the caregiving mother to increase and the BDI to decrease. When the studies researching the caregiver's strain index of mothers of children with $\mathrm{CP}$ are investigated, it is found that the caregiving burden of the mothers increase with the increasing role of the family in taking care of the child [21,22]. In another study, it was seen that the incidence of psychological problems increase in the mothers of children with MR when compared to those of children who do not have MR [23-25].

The results of our study indicate that the better the motor development level of a disabled child, the more positive change and less depressive symptoms in a mother during the caregiving process. The lack of difference in the comparison of the BCOS and BDI of the mothers of children with $\mathrm{CP}$ and MR show that the mothers of both groups get similarly affected by the motor development levels of their children.

\section{Limitations of this study were;}

- $\quad$ The number of subjects were less

- $\quad$ There were no healthy control group

At the light of these results, we believe that BCOS and CSI can be used to determine how the stress levels and caregiving burdens change in the mothers of children with $\mathrm{CP}$ and MR.

Our results in terms of higher stress burden among CP diagnosed children's mothers in comparison to MR diagnosed children's mothers may be related with the higher motor development problems that we see in CP diagnosed children.

Based on our results which are backed up by the literature, considering the role of the family and especially the mother in the rehabilitation team of her child with CP and MR, the negative impact a mother's caregiving burden and stress on the rehabilitation of the child and the importance of the determination of these problems of the mother can be seen more clearly $[2,26,28]$.

The number of studies done in Turkey on this area -especially in physical therapy- is very small. The literature should be enriched in this regard. This study was conducted to provide information to clinicians and researchers about the burden of care for children with CP and MR.

It should not be forgotten that increasing the level of education and the knowledge of children about problems with mothers who have children with neurological situations, such as children with $\mathrm{CP}$ and MR, may positively affect caregiving burdens and depression levels.

All the medical staff from any disciplin who attend the treatment program of these children should take into account while planning the treatment program that these children's quality of life level's decreases but level of depression and burden of caregiving increases.

Disclosure Statement: The authors declare no conflict of interests. 


\section{References}

1. Bax M, Goldstein M, Rosenbaum P, et al. Proposed definition and classification of cerebral palsy. Dev Med Child Neurol 2005;47:571-577.

2. Piştav Akmeşe $P$, Mutlu A, Kerem Günel M. Serebral paralizili çocukların annelerinin kaygı düzeyinin araştırılması. Çocuk Sağlığı ve Hastalıkları Dergisi 2007;50:236-240.

3. Vergili Ö, Oktaş B, Koçulu E. Engelli çocuğun bağımsızlık düzeyinin kendisine bakım verenler üzerindeki sağlıkla îlgili yaşam kalitesi açısından etkisinin incelenmesi. Hacettepe University Faculty of Health Sciences Journal 2015;2:15-21

4. Peker F. Serebral palsili çocuğa sahip ailelerde algılanan sosyal desteğin anne babaların depresyon düzeyi ile ilişkisi. Yayınlanmış Yüksek Lisans Tezi. Ankara Üniversitesi/Sağlık Bilimleri Enstitüsü/ Disiplinlerarası Sosyal Psikiyatri Anabilim Dalı, Ankara, 2007.

5. Şengül S, Baykan H. Zihinsel engelli çocukların annelerinde depresyon, anksiyete ve stresle başa çıkma tutumları. Kocatepe Tıp Derg 2013;14:30-39.

6. Can T. Bakas caregiving outcomes scale'in (Bakas bakım verme etki ölçeği) Türkçe'ye uyarlanması, geçerlilik ve güvenirliliği, Doktora Tezi, Pamukkale Üniversitesi Sağlık Bilimleri Enstitüsü, Denizli, 2010.

7. Taşdelen $P$, Ateş M. Evde bakım gerektiren hastaların bakım gereksinimleri ile bakım verenlerin yükünün değerlendirilmesi. HEAD 2012;9:22-29.

8. Palisano RJ, Cameron D, Rosenbaum PL, Walter SD, Russell D. Stability of the gross motor function classification system. Dev Med Child Neurol 2006;48:424-428.

9. Robinson BC. Validation of a caregiver strain index. J Gerontol 1983;38:344-348.

10. Uğur Ö, Fadıloğlu Ç. 'Caregiver stres index' validity and realibility in Turkish society. Asian Pac J Cancer Prev. 2010;11:1669-1675.

11. Bakas T, Champion V, Perkins SM, Farran CJ, Williams LS. Psychometric testing of the revised 15-item bakas caregiving outcomes scale. Nurs Res 2006;55:346355.

12. Bakas T, Champion V. Development and psychometric testing of the bakas caregiving outcomes scale. Nurs Res 1999;48:250-259.

13. Hisli N. Beck depresyon envanterinin geçerliliği üzerine bir çalışma (in Turkish). Psikoloji Dergisi 1988;6:118126.

14. Jhansen R, Aamodt G, Rosenbaum P. Gross motor function classification system used in adults with cerebral palsy: agreement of self-reported versus professional rating. Dev Med Child Neurol 2006;48:734738.

15. McCormickA, Brien M, Plourde J, Wood E, Rosenbaum $P$, McLean J. Stability of the gross motor function classification system in adults with cerebral palsy. Dev Med Child Neurol 2007;49:265-269.
16. El O, Baydar M, Berk H, Peker O, Kosay C, Demiral Y. Interobserver reliability of the Turkish version of the expanded and revised gross motor function classification system. Disabil Rehabil 2012;34:10301033.

17. Kavlak E, Altuğ F, Büker N, Şenol H. Musculoskeletal system problems and quality of life of mothers of children with cerebral palsy with different levels of disability. J Back Musculoskelet Rehabil 2015;28:803810.

18. Sade Ave Otman AS. Serebral paralizi'de değerlendirme ve tedavi yöntemleri, Hacettepe Üniversitesi Fizik Tedavi ve Rehabilitasyon Yüksekokulu Yayınları; 1991.

19. Akkök F. Özürlü bir çocuğa sahip anne-babaların kaygı ve endişe düzeyini ölçme aracının güvenirlik ve geçerlik çalışması. Psikoloji Dergisi 1989;23:26-39.

20. Karahan AY, İslam S. Fiziksel engelli çocuk ve yaşı। hastalara bakım verme yükü üzerine bir karşılaştırma çalışması. MÜSBED 2013;3:1-7.

21. Rosen MG, Dickinson JC. The incidence of cerebral palsy. Am J Obstet Gynecol 1992;167:417-423.

22. Atagün Mi, Balaban ÖD, Atagün Z, Elagöz M, Yılmaz Özpolat A. Kronik hastalıklarda bakım veren yükü. Psikiyatride Güncel Yaklaşımlar 2011;3:513-552.

23. Miller AC, Gordon RM, Daniele RJ, Diller L. Stress, appraisal and coping in mothers of disabled and nondisabled children. J Pediatr Psychol 1992;17:587605.

24. Hanson MJ, Hanline MF. Parenting a child with a disabilities: a longitudinal study of parental stress and adaptation. J Early Intervent 1994;14:234-248.

25. Uğuz Ş, Toros F, Yazgan İnanç B, Çolakkadıoğlu O. Zihinsel ve/veya bedensel engelli çocukların annelerinin anksiyete, depresyon ve stres düzeylerinin belirlenmesi. Klinik Psikiyatri 2004;7:42-47.

26. Wendt L, Ekenberg L, Dagis D, Janlert UA. A parent-centered approach to physiotherapy for their handicapped children. Dev Med Child Neurol 1984;26:445-448.

27. Hanft $B$. The changing environment of early intervention services: implications for practice. Am J Occup Ther 1988;42:724-731. 